QUARTERLY REPORT

Methane Formation and Retention in Coal

Technical Progress Report DOE-PC88939-10

July 1, 1990 - September 30, 1990

Contract Number DE-FG22-88PC88939

V. Joseph Hucka, Principal Investigator

Department of Mining Engineering

University of Utah

Salt Like City, Utah 84112

\title{
OBJECTIVE
}

The methane content of coal seams in Utah and colorado will be measured in situ as well as in the laboratory and correlated with the geological and geochemical history of the seams and surrounding strata. Chemical and physical properties will be measured in the laboratory for coals that contain methane and coals of similar rank which do not contain methane. Methane yields on pyrolysis will be used to measure the propensity of coals to form additional methane. Methane formation and retention will be interpreted in terms of the physical and chemical properties of the coal and the chemical and geological history of the coal seam.

\section{PROJECT STATUS}

\section{Field Tests}

Routine field tests were conducted for in situ methane determination and coal samples collected at the soldier Creek Coal Mine of the Book Cliffs field near Price in central Utah. The tests were performed in the sunnyside seam. Three 5-meter boreholes were drilled into a pillar in a freshly opened area. The fine cuttings were evaluated for methane content by use of the bubble desorbometer and also in a special six-cell electronic methanometer manufactured in Japan. The first results indicate a methane content of 1.2 cubic meter per one metric tonne of coal. The methanometer, which is controlled by a microprocessor, was loaned to the project by Dr. Kotaro Ohga, Professor of Mining Engineering, Hokkaido University, Sapporo, Japan. In August 1990, Dr. Ohga joined our Department for a 9-month sabbatical leave. He is now participating on this project. Coal samples were also collected in canisters for laboratory evaluation.

The boreholes for sample collection were also used for installing 5-meter long metal pipes. The pipes were cemented into the boreholes and pressure gauges mounted on the ends of the pipes 
to measure methane buildup inside the boreholes. A mechanical flowmeter was also instailed on one of the pipes. So far only a slight pressure has been registered. Consequently, it is has been decided to repeat these tests to obtain information on methane pressure inside the sunnyside seam.

Coal samples were also collected from the remaining coal mines belonging to the Book Cliffs field. The samples were collected from Sunnyside, Gilson and Castle Gate A seams of the Anadalex Coal Mine. The samples are presently being tested for proximate analysis and NMR spectroscopy. This sampling practically concludes the coal sample collections portion of this project.

\section{Laboratory 'Tests on Pyrolysis}

The coal pyrolysis system was described in the previous report (1). The system has been used to charactorize the pyrolysis behavior of Dutch Creek coal from Colorado, six samples from different mines in the Book Cliffs coal field, Utah and two samples from the wasatch Plateau coal field, Utah. The location of the Utah coal mines were shown previously (1). Methane evolution and total gas evolution were measured in one experiment. Methane, carbon dioxide, carbon morioxide and $\mathrm{C}_{2}$ and $\mathrm{C}_{3}$ hydrocarbon gases were measured in separate experiments using a gas chromatograph detector and helium carrier gas. Hydrogen and methane were measured in additional experiments using the gas chromatograph and argon carrier gas.

The reproducibility of the equipment is demonstrated in figures 1-4. The linearity of the heating rate is shown in figure 1. There is a slight deviation from linearity at the temperature of rapid devolitilization for some coal samples. About 4,500 temperature measurements are taken in the range of gas evolution measurements and the heating is found to be linear with a correlation coefficient greater than 0.9999. The heating rate was controlled at $12.2{ }^{\circ} \mathrm{C} / \mathrm{min}$. The methane concentration as determined by the methane detector with infrared cell is shown in figure 2 for tri.plicate experiments for sunnyside coal. The results are typical of the reproducibility obtained for other samples. The yield of methane, initial evolution temperature and temperature of maximum evolution are very similar. The methane yields determined by gas chromatography are similar to those obtained with the methane monitor.

The effect of particle size was determined for three coals, the medium volatile Dutch Creek coal, the high volatile and gassy Sunnyside coal and the high volatile and non-gassy skyline coal. A -100 mesh fraction, a $-60 /+100$ mesh fraction and a +60 mesh fraction were tested. The results for methane evolution are shown in figure 3 and the results for hydrogen evolution in figure 4 for Sunnyside coal. These results are typical of those obtained for each of the three coals tested. The results indicated little 
effect of particle size under the conditions of these experiments aid the remaining coals were studied using only the $-60 /+100$ mesh fractions. Particle size effects might be expected at higher heating rates.

The experimental results from the Sunnyside $-60 /+100$ mesh coal sample will be used to illustrate the details of the results. The total flow of gaseous products in shown in figure 5, as measured by mass flow meters. The flow rate of helium is measured prior to entering the pyrolysis reactor and subtracted from the total flow to obtain the net flow of pyrolysis gases. The volume of gases has been corrected to $0^{\circ} \mathrm{C}$ and one atmosphere pressure and the yield is corrected to a dry, ash-free coal basis. Methane is measured continuously by the IR methane monitor. Other gaseous products are determined by gas chromatography. Figure 6 shows the gas chromatograms obtained at different temperatures using helium carrier gas. Figure 7 shows similar results for argon carrier gas. The yield of gas can be determined directly from the gas chromatographic response $o_{i}$ from the gas composition and the total flow rate. Comparable results are obtained by the two methods. Methane yields also compare with measurements by the methane monitor. The calculation of yields for individual gas species is shown in figure 8. A curve fitting program was used to draw the solid lines. The smoothed curves are plctted as a function of temperature in figure 9. The sum of the gases yields agrees with the total gas evolution. Hydrogen gases are evolved at lower temperatures with carbon oxides and hydrogen evolved at higher temperatures. These results are as expected and agree with reported results (2).

Cumulative gas production is shown as a function of time in figure 10. The sample is held at $900{ }^{\circ} \mathrm{C}$ until gas evolution is complete. Hence the cumulative product includes contributions from the linear heating period and from the isothermal period.

Gaseous product 'ilelds are shown as functions of temperature for the other coals of this study in figures 11-18. A similar behavior is noted for all coals, with the higher rank Dutch Creek coal showing higher initial temperatures for gas evolution. The characteristic temperatures, evolution rates and yields are listed in table 1 for each of the coals.

\section{FUTURE STUDIES}

Pyrolysis

Additional pyrolysis experiments will be conducted to cover a lower heating rate and a wider range of coal rank. The results of the pyrolysis experiments will be compared with the NMR dipolardephasing results and.with methane content of the coal seams. Densities will be measured in a helium pycnometer. 


\section{REFERENCES}

1. V. T Hucka and D. M. Bodily, "Methane Formation and Retention in Coal", Quarterly Report, April 1, 1990 to June 30, 1990, Contract Number DE-FG22-88PC88939.

2. Howard, J. B., "Fundamentals of Coal Pyrolysis and Hydropyrolysis", Chemistry of Coal Utilization, 2nd suppl. volume, Elliot, M. A., Ed., Wiley-Interscience, N. Y., 1981 . 
Table 1 Characteristic Pyrolysis Parameters

\begin{tabular}{ccccc}
\hline & & & & \\
Initial & Max. Rate & Max. & Tot.d & Percent \\
Temp. & Temp. & $\begin{array}{l}\text { Rate } \\
\text { Yield* }\end{array}$ & Total \\
C & $C$ & $m l / g$ & \\
\hline
\end{tabular}

Sunnyside

\begin{tabular}{|c|c|c|c|c|c|}
\hline $\mathrm{CH} 4$ & 309 & 500 & 0.0683 & 62.4 & $18.6 \%$ \\
\hline $\mathrm{C} 2 \mathrm{H} 4$ & 387 & 482 & 0.0018 & 0.9 & $0.3 \%$ \\
\hline $\mathrm{C} 2 \mathrm{H} 6$ & 387 & 482 & 0.0153 & 7.3 & $2.2 \%$ \\
\hline$H 2$ & 383 & 764 & 0.160 & 208 & $61.9 \%$ \\
\hline$C O$ & 91 & 741 & 0.0257 & 44.7 & $13.3 \%$ \\
\hline \multirow[t]{2}{*}{$\mathrm{CO} 2$} & 91 & 481 & 0.0089 & 12.4 & $3.7 \%$ \\
\hline & & & & 336 & $100 \%$ \\
\hline
\end{tabular}

Skyline

\begin{tabular}{|c|c|c|c|c|c|}
\hline $\mathrm{CH} 4$ & 269 & 554 & 0.0520 & 60.5 & $17.0 \%$ \\
\hline $\mathrm{C} 2 \mathrm{H} 4$ & 378 & 502 & 0.0016 & 1.1 & $0.3 \%$ \\
\hline $\mathrm{C} 2 \mathrm{H} 6$ & 378 & 502 & 0.0122 & 7.2 & $2.0 \%$ \\
\hline$H 2$ & 352 & 769 & 0.169 & 199 & $56.1 \%$ \\
\hline $\mathrm{CO}$ & 90 & 768 & 0.0516 & 65.1 & $18.3 \%$ \\
\hline $\mathrm{CO} 2$ & 90 & 442 & 0.0138 & 22.2 & $6.3 \%$ \\
\hline
\end{tabular}

Dutch Creek

$\begin{array}{lrrrrr}\mathrm{CH} 4 & 419 & 502 & 0.157 & 73.5 & 17.8 \% \\ \mathrm{C} 2 \mathrm{H} 4 & 450 & 505 & 0.0036 & 0.8 & 0.2 \% \\ \mathrm{C} 2 \mathrm{H6} & 450 & 505 & 0.0286 & 7.5 & 1.8 \% \\ \mathrm{H} 2 & 366 & 731 & 0.198 & 298 & 72.3 \% \\ \mathrm{CO} & 129 & 732 & 0.0192 & 27.0 & 6.6 \% \\ \mathrm{CO} 2 & 129 & 505 & 0.0044 & 5.0 & 1.2 \% \\ & & & & & \\ & & & & & \\ & & & & & \\ & & & & & \\ \end{array}$


Tajie i Characteristic Pyrolysis Parameters (Continued)

\begin{tabular}{ccccc}
\hline & & & & \\
Initial & Max. Rate & Max. & Total & Percent \\
Temp. & Temp. & Rate & Yield & Total \\
$C$ & $C$ & $m l /(s e c).(g)$ & $m l / g$ & \\
\hline
\end{tabular}

Soldier Creek

$\mathrm{CH} 4$
$\mathrm{C} 2 \mathrm{H} 4$
$\mathrm{C} 2 \mathrm{H} 6$
$\mathrm{H} 2$
$\mathrm{CO}$
$\mathrm{CO} 2$

$\begin{array}{rr}300 & 539 \\ 346 & 487 \\ 346 & 487 \\ 384 & 762 \\ 88 & 765 \\ 88 & 470\end{array}$

0.0570
0.0016
0.0142
0.170
0.045
0.013

64.1

$64.1 \quad 17.9$

$0.8 \quad 0.2$

$7.5 \quad 2.1$

$\begin{array}{rrr}0.0142 & 7.5 & 2.1 \\ 0.170 & 205 & 57.2\end{array}$

$\begin{array}{lrr}0.170 & 205 & 57.2 \\ 0.0456 & 58.1 & 16.2\end{array}$

$\begin{array}{lll}0.0131 & 22.6 & 6.3\end{array}$

total:

$358 \quad 100$

\section{Castle Gate}

$\mathrm{CH} 4$
$\mathrm{C} 2 \mathrm{H} 4$
$\mathrm{C} 2 \mathrm{H} 6$
$\mathrm{H} 2$
$\mathrm{CO}$
$\mathrm{CO} 2$

298

492

504

504

729

731

504

0.157
0.0036
0.0286
0.198
0.0456
0.0131

69.3

18.7

376

365

108

108

504

\begin{tabular}{lll}
0.0131 & 18.1 & 4.9 \\
\cline { 2 - 3 } total: & 371 & 100
\end{tabular}

Aberdeen

\begin{tabular}{|c|c|c|c|c|c|}
\hline $\mathrm{CH} 4$ & 348 & 524 & 0.0655 & 67.6 & 19.3 \\
\hline $\mathrm{C} 2 \mathrm{H} 4$ & 410 & 487 & 0.0020 & 0.9 & 0.3 \\
\hline $\mathrm{C} 2 \mathrm{H} 6$ & 410 & 487 & 0.0151 & 6.8 & 1.9 \\
\hline$H 2$ & 391 & 749 & 0.148 & 199 & 56.7 \\
\hline$C O$ & 119 & 744 & 0.0319 & 59.2 & 16.9 \\
\hline \multirow[t]{2}{*}{$\mathrm{CO} 2$} & 119 & 471 & 0.0141 & 17.2 & 4.9 \\
\hline & & & & 351 & 100 \\
\hline
\end{tabular}


Table 1 Characteristic Pyrolysis Parameters (Continued)

\begin{tabular}{ccccc}
\hline & & & & \\
Initial & Max. Rate & Max. & Total & Percent \\
Temp. & Temp. & Rate & Yield & Total \\
$C$ & $C$ & $m l /(\sec ).(g)$ & mI/g &
\end{tabular}

Apex

$\begin{array}{lrrrrr}\mathrm{CH} 4 & 335 & 527 & 0.055 & 60.4 & 17.4 \\ \mathrm{C} 2 \mathrm{H} 4 & 400 & 504 & 0.0036 & 0.711 & 0.2 \\ \mathrm{C} 2 \mathrm{H6} & 400 & 504 & 0.0286 & 5.67 & 1.6 \\ \mathrm{H} 2 & 378 & 730 & 0.198 & 200 & 57.6 \\ \mathrm{CO} & 97 & 732 & 0.0192 & 64.2 & 18.5 \\ \mathrm{CO} 2 & 97 & 504 & 0.0044 & 16.5 & 4.8 \\ & & & & 347 & 100\end{array}$

Pinnacle

$\begin{array}{lrrrrr}\mathrm{CH} 4 & 347 & 541 & 0.0521 & 55.1 & 15.8 \\ \mathrm{C} 2 \mathrm{H} 4 & 425 & 505 & 0.0016 & 1.0 & 0.3 \\ \mathrm{C} 2 \mathrm{H6} & 425 & 505 & 0.0133 & 5.6 & 1.6 \\ \mathrm{H} 2 & 391 & 782 & 0.156 & 198 & 56.7 \\ \mathrm{CO} & 99 & 760 & 0.0453 & 68.5 & 19.6 \\ \mathrm{CO} 2 & 99 & 473 & 0.0130 & 21.1 & 6.0 \\ & & & & & \\ & & & & & \\ & & & & & \\ & & & & & \end{array}$

\section{SUFCO}

$\begin{array}{lrrrrr}\mathrm{CH} 4 & 294 & 517 & 0.0538 & 60.4 & 17.1 \\ \mathrm{C} 2 \mathrm{H} 4 & 369 & 483 & 0.0016 & 0.8 & 0.2 \\ \mathrm{C} 2 \mathrm{H6} & 369 & 483 & 0.0130 & 5.9 & 1.7 \\ \mathrm{H} 2 & 368 & 771 & 0.149 & 199 & 564 \\ \mathrm{CO} & 86 & 748 & 0.0490 & 60.8 & 17.2 \\ \mathrm{CO} 2 & 86 & 437 & 0.0168 & 26.2 & 7.4 \\ & & & & & \\ & & & & & \\ & & & & & \\ & & & & & \\ & & & & & \end{array}$

* The complete units for the Max. Rate and Total Yield are $\mathrm{ml}(\mathrm{STD}) /(\mathrm{sec}).(\mathrm{g}$ d.a.f. coal) and $\mathrm{ml}(\mathrm{STD}) /(\mathrm{g}$ d.a.f. coal) respectively. 


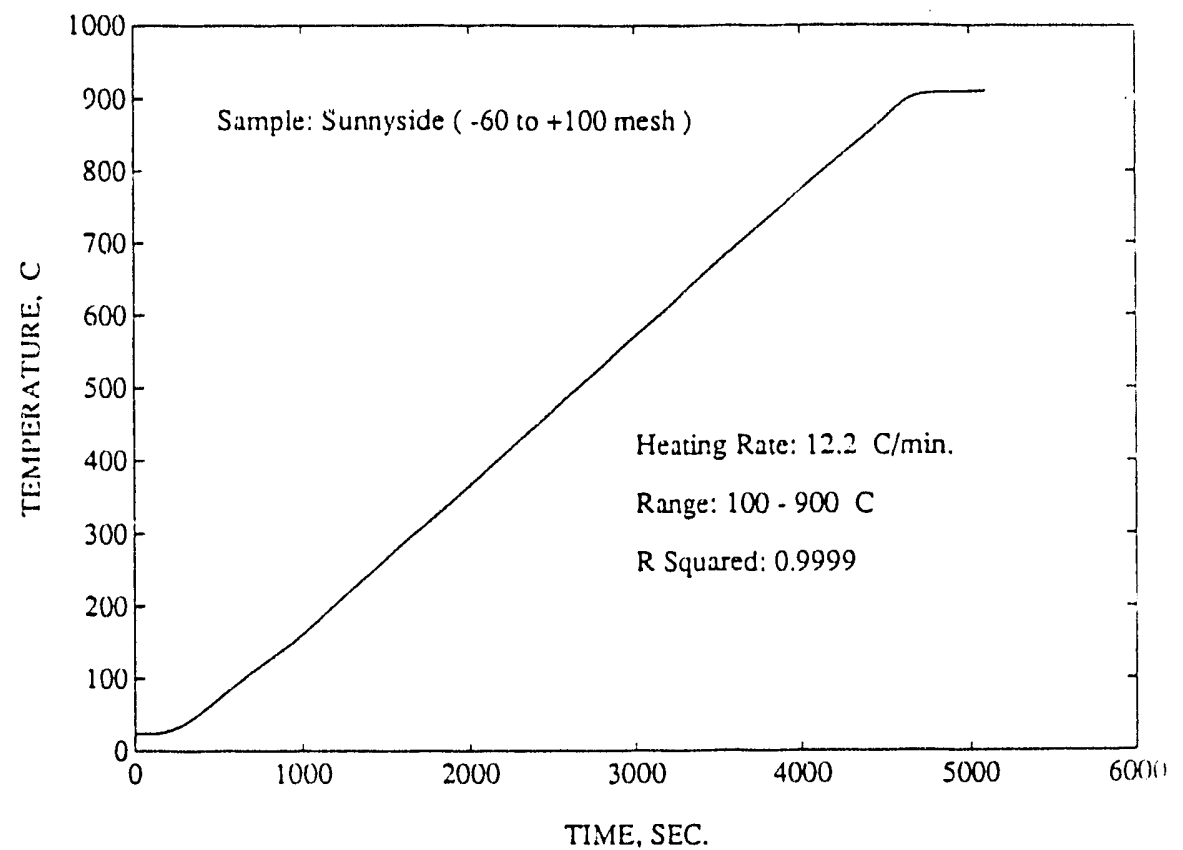

Figure 1. Heating profile.

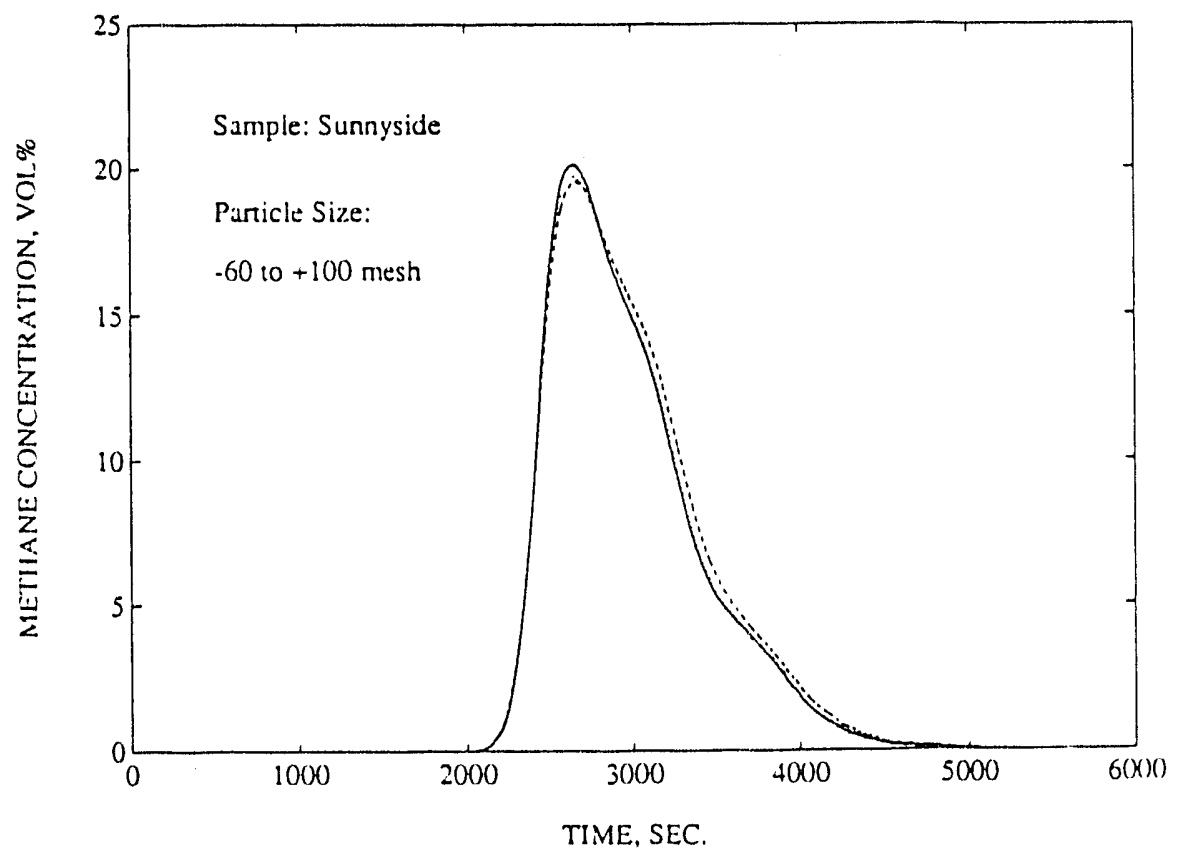

Figure 2. Reproducibility of methane evolution for triplicate experiments. 


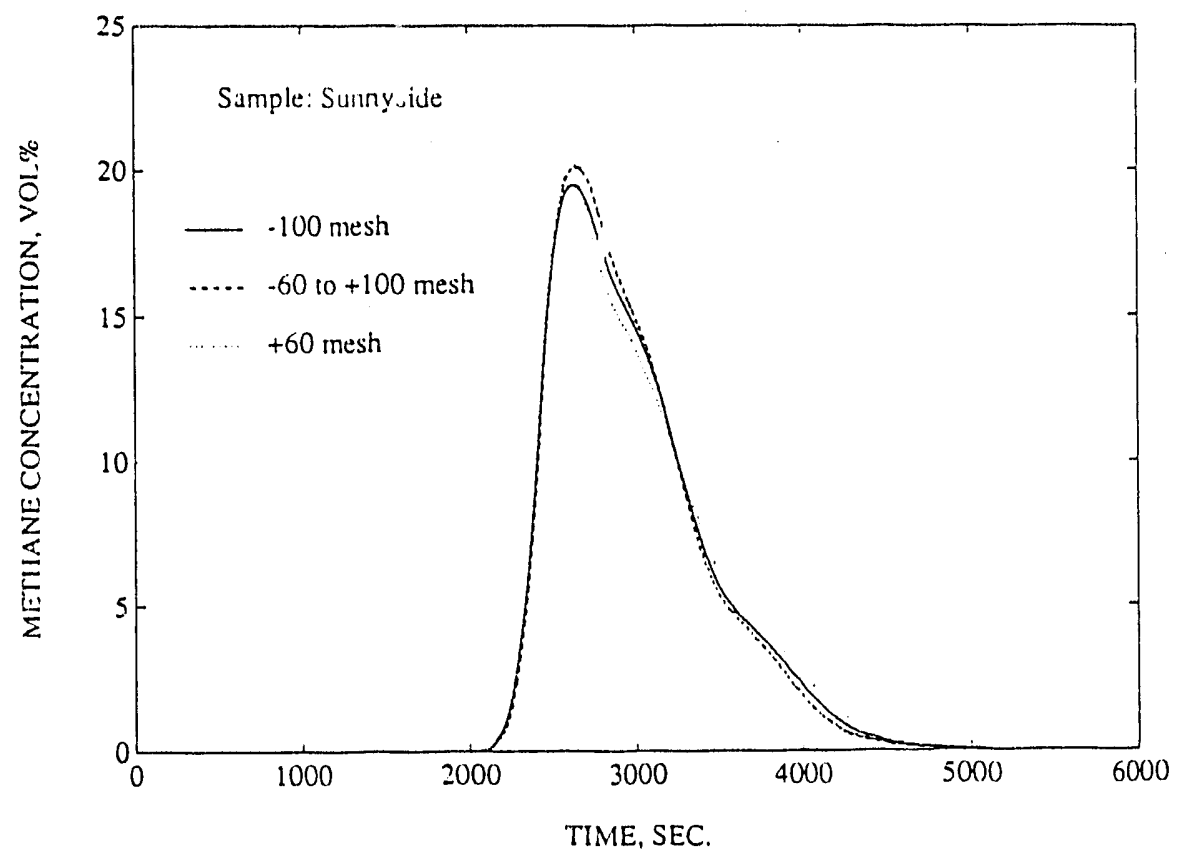

Figure 3. Effect of particle size on methane evolution.

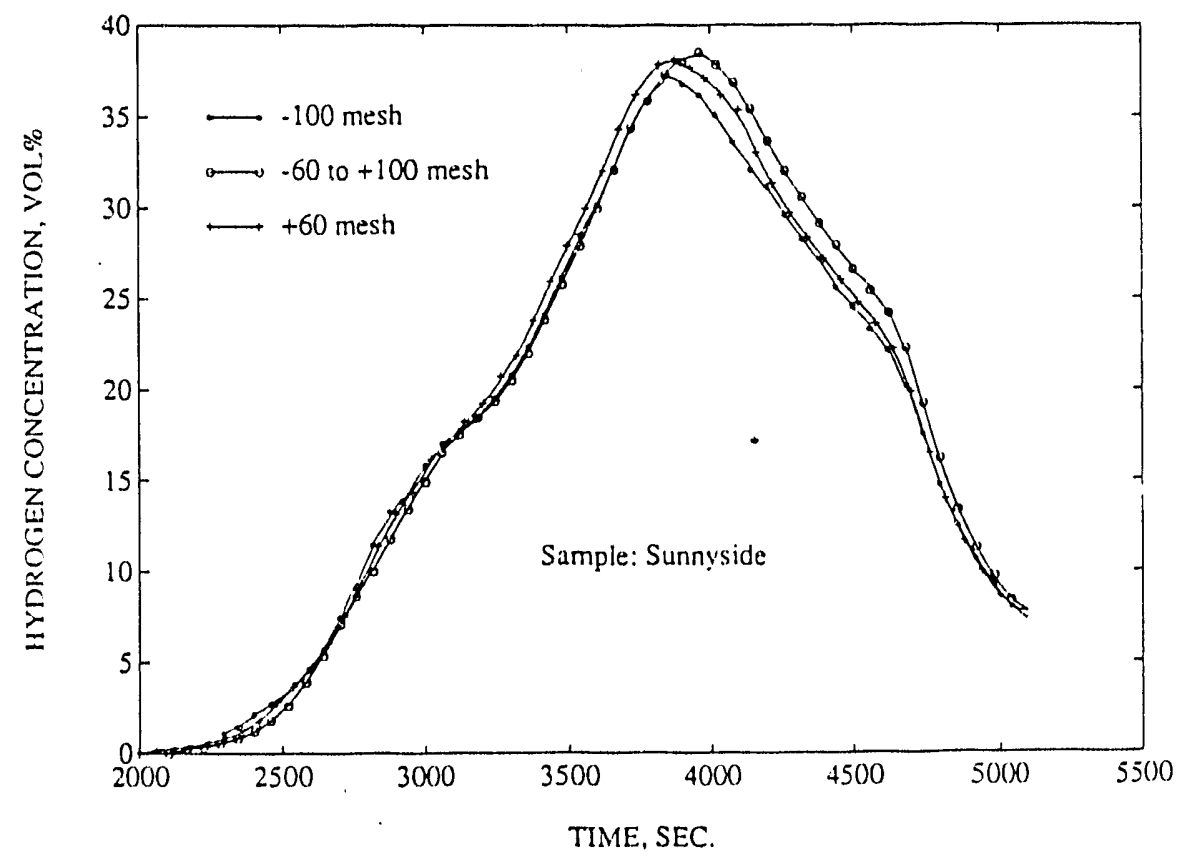

Figure 4. Effect of particle size on hydrogen evolution. 


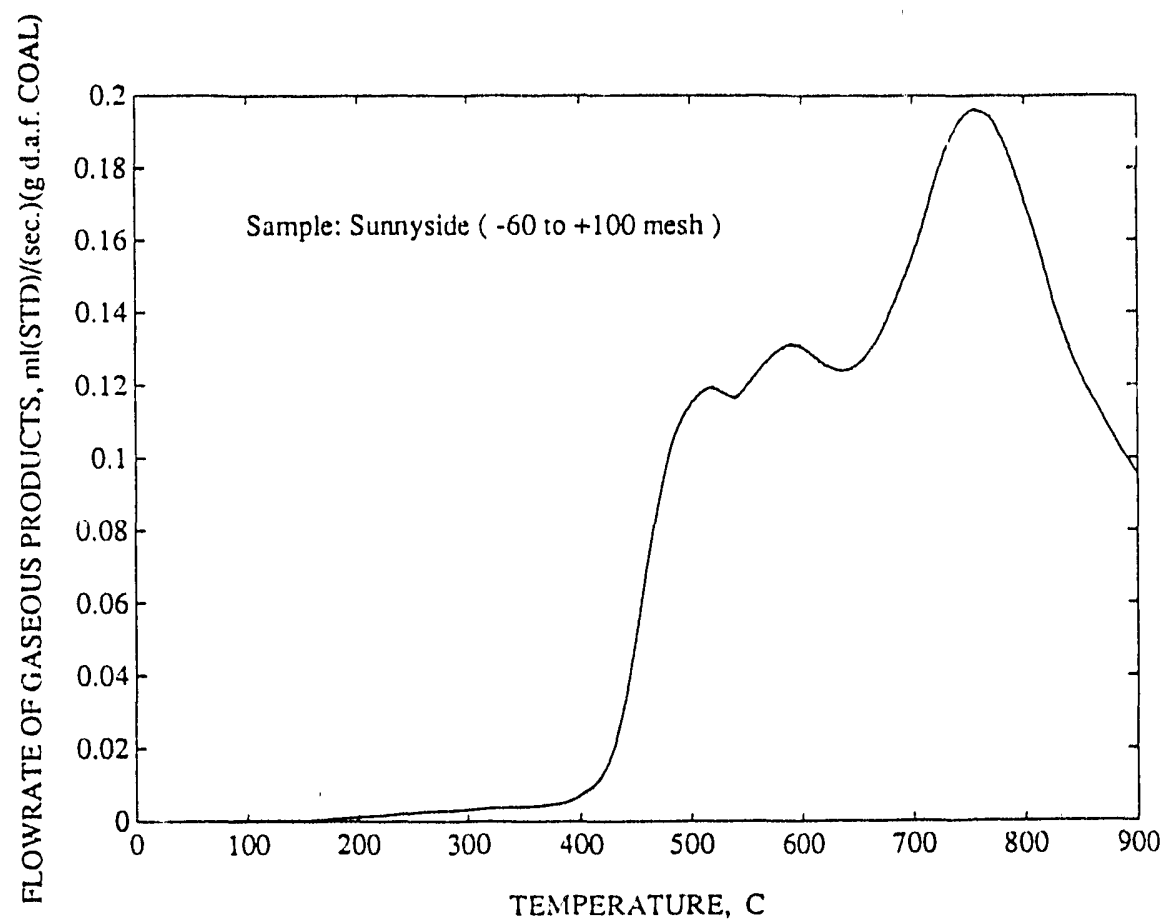

Figure 5. Total flow rate of gaseous pyrolysis products.

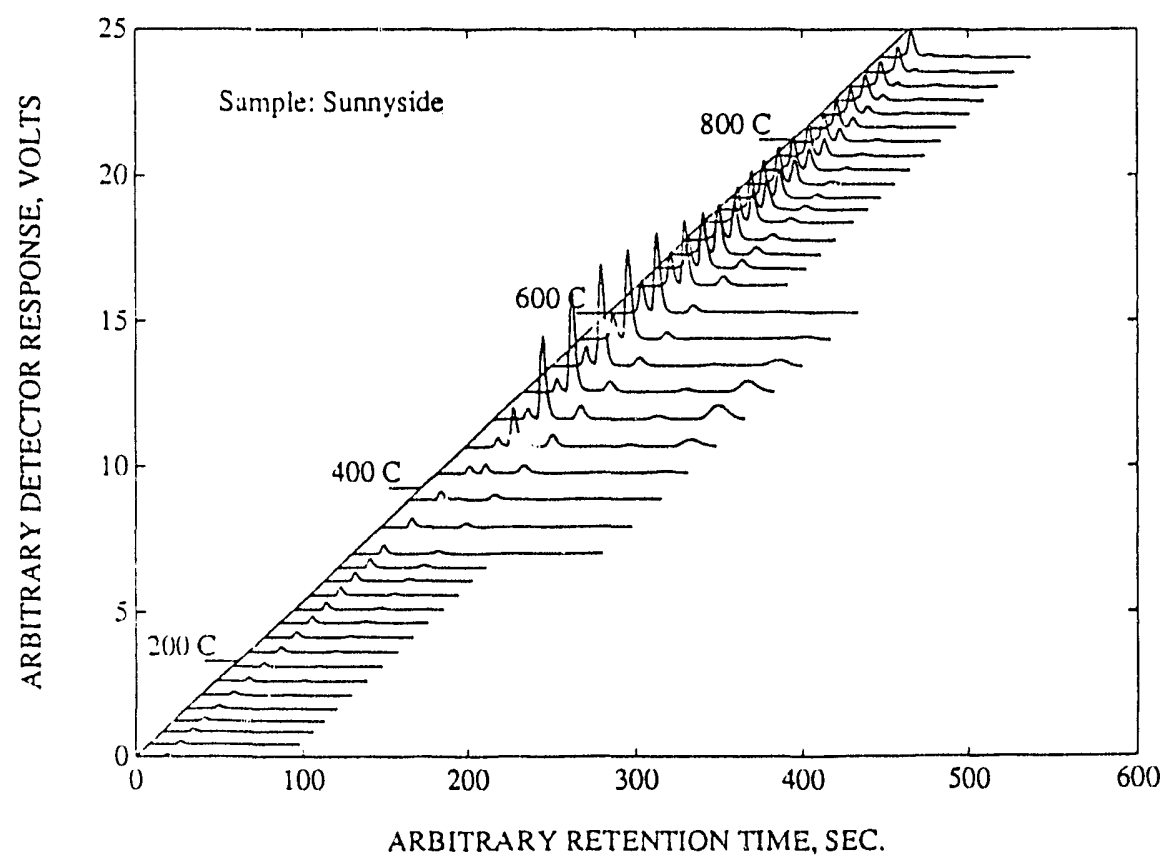

Figure 6. Gas chromatograms of gaseous products using helium as carrier gas. The elution sequence is $\mathrm{CO}, \mathrm{CH}_{4}$, , $\mathrm{CO}_{2}, \mathrm{C}_{2} \mathrm{H}_{4}$ and $\mathrm{C}_{2} \mathrm{H}_{6}$. 


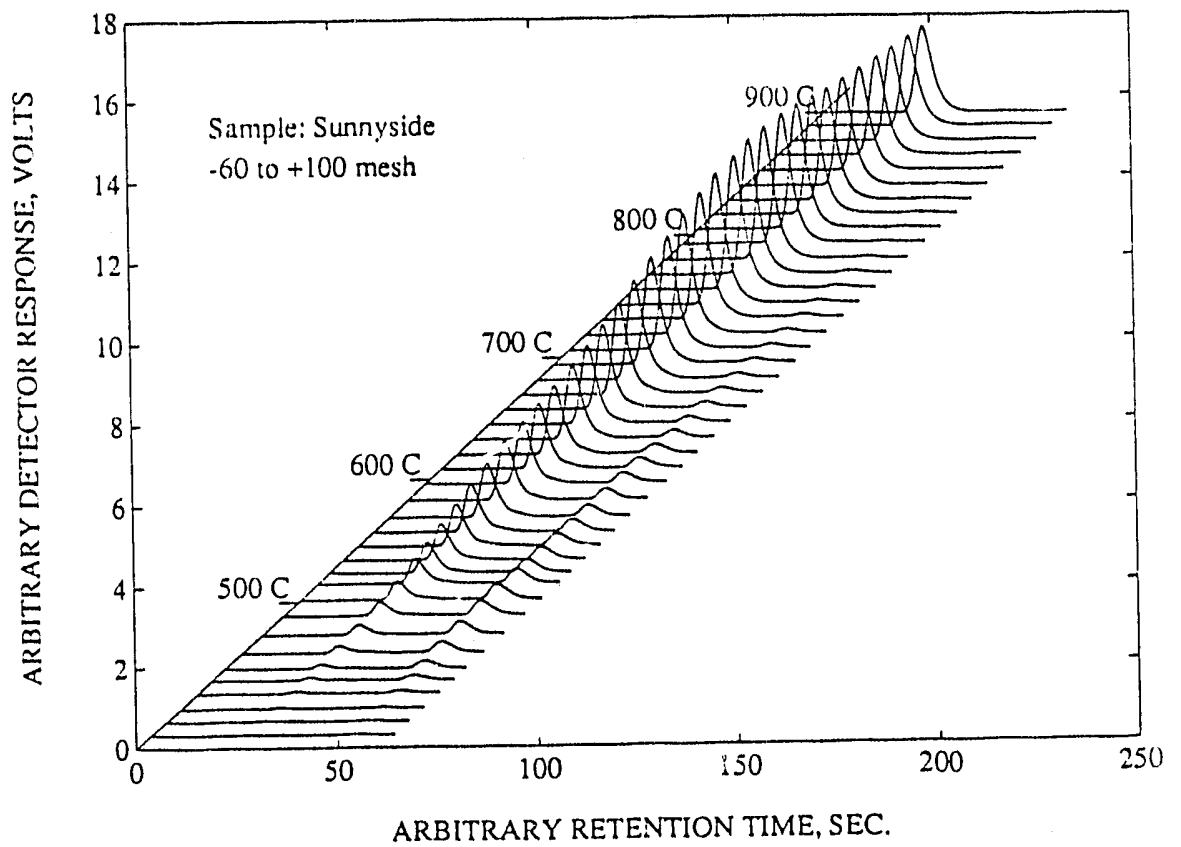

Figure 7. Gas chromatograms of gaseous products using argon as carrier gas. The elution sequence is $\mathrm{H}_{2}$ and $\mathrm{CH}_{4}$.
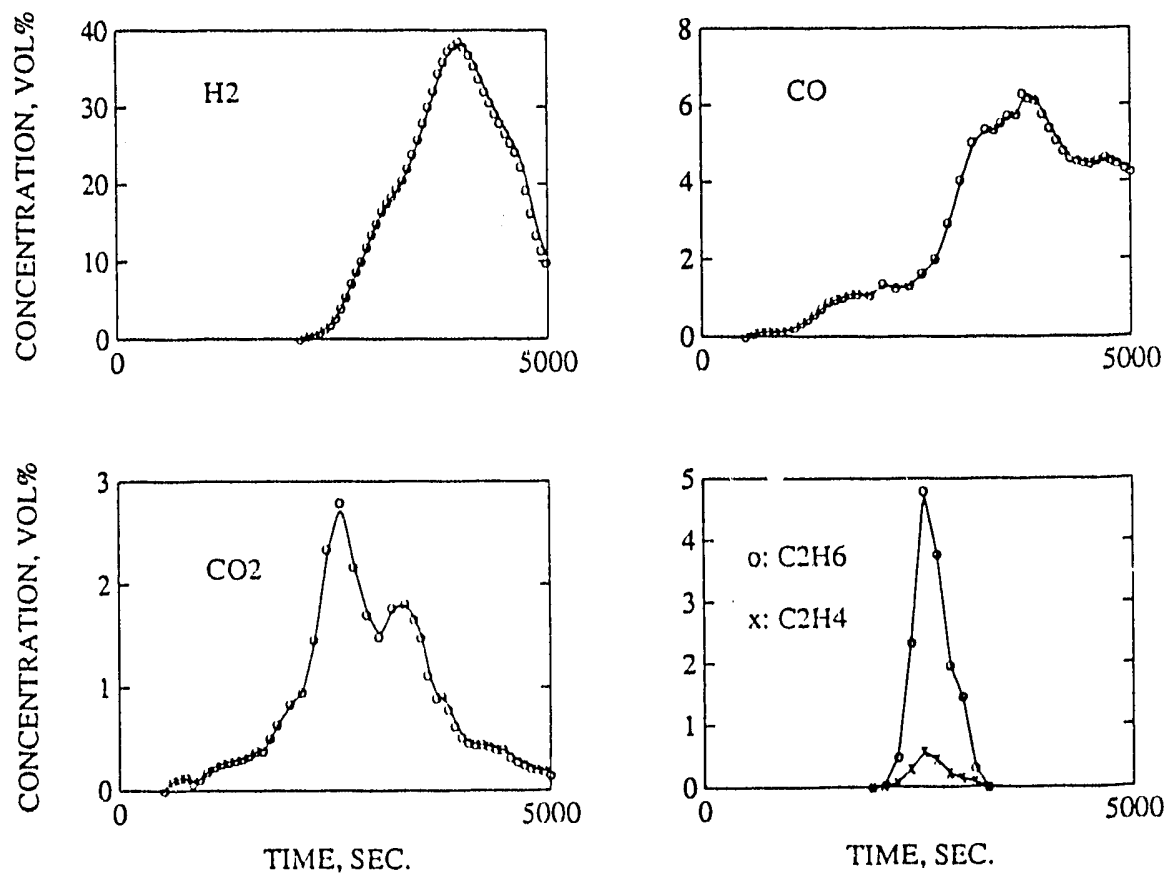

Figure 8. Pyrolysis gas yields. 


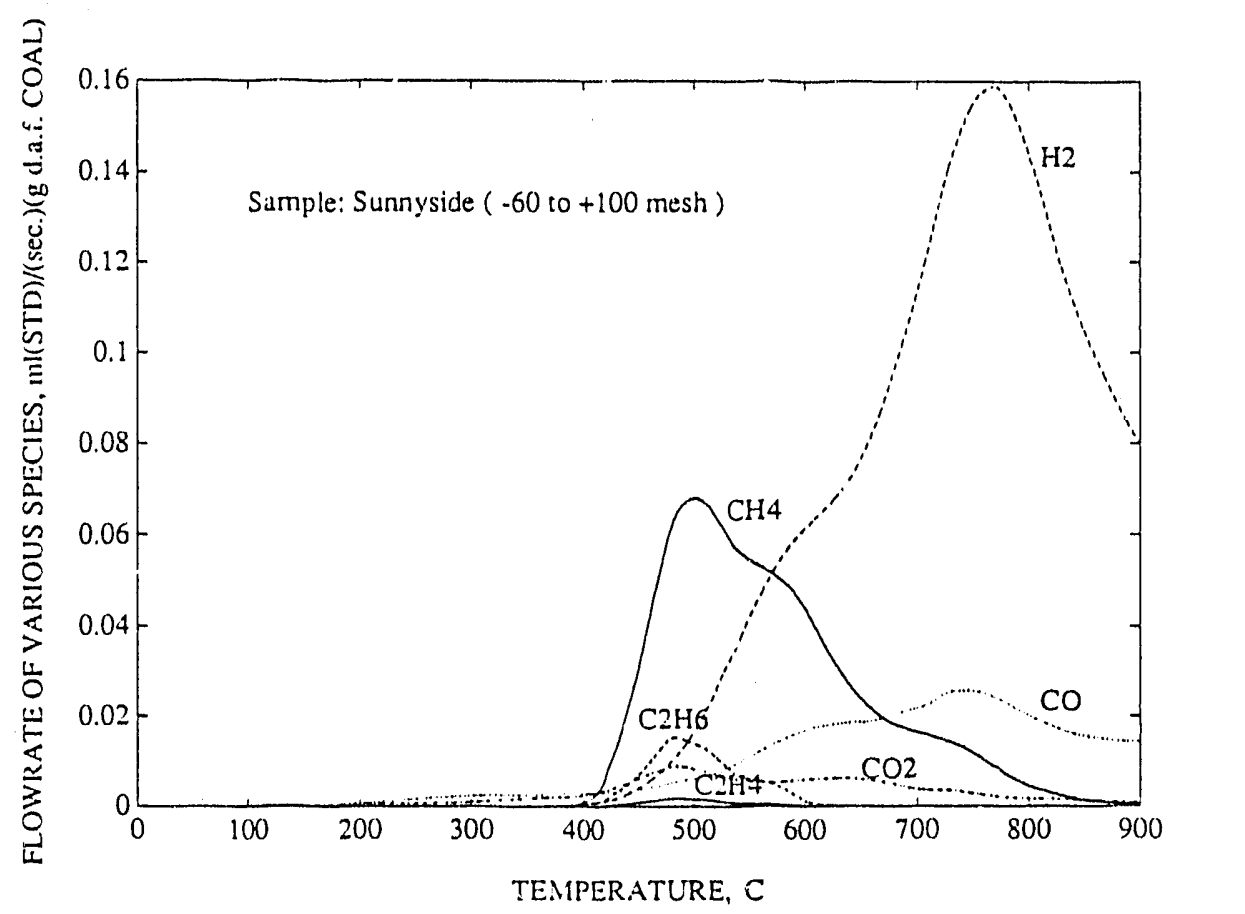

Figure 9. Pyrolysis gas yields as a function of temperature for Sunnyside coal.

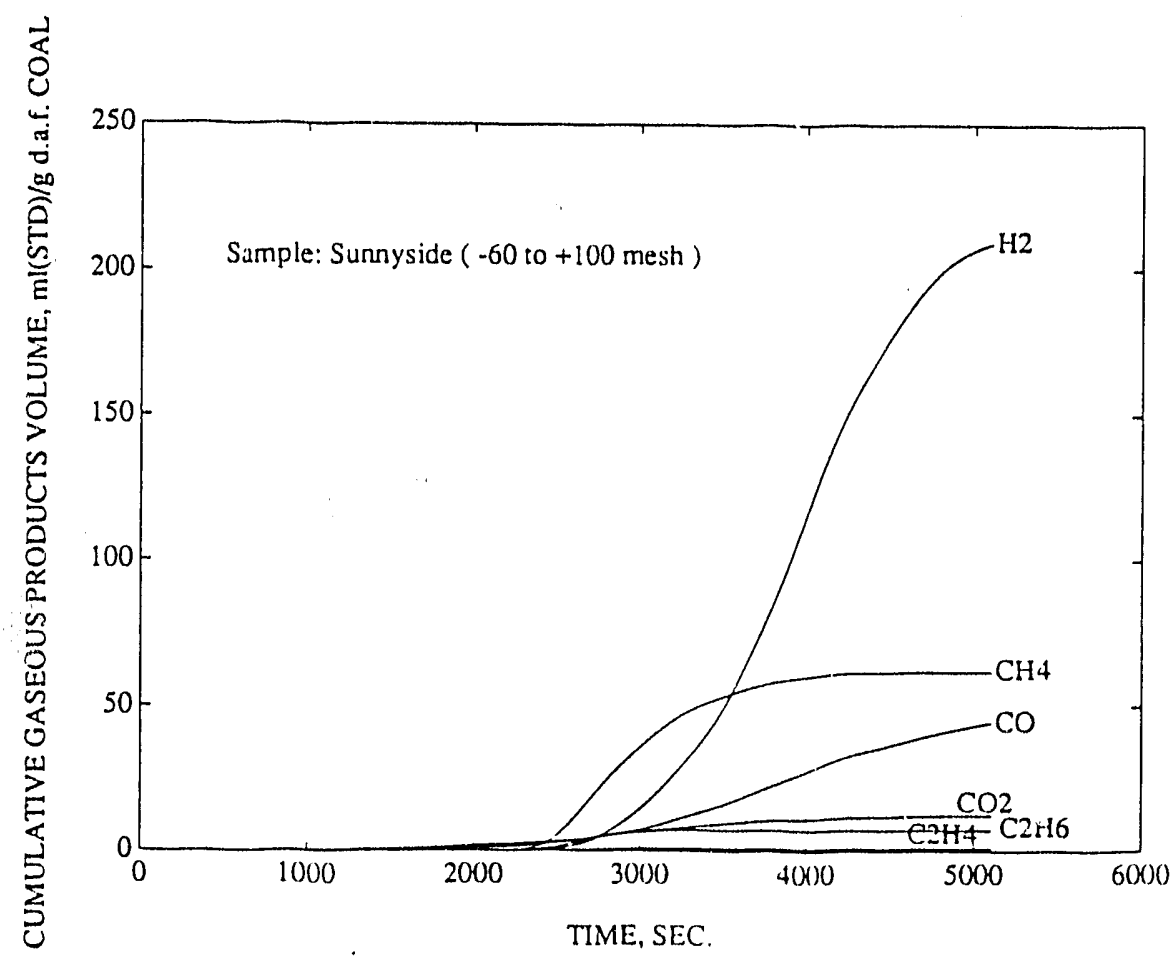

Figure 10. Cumulative pyrolysis gas yields. 


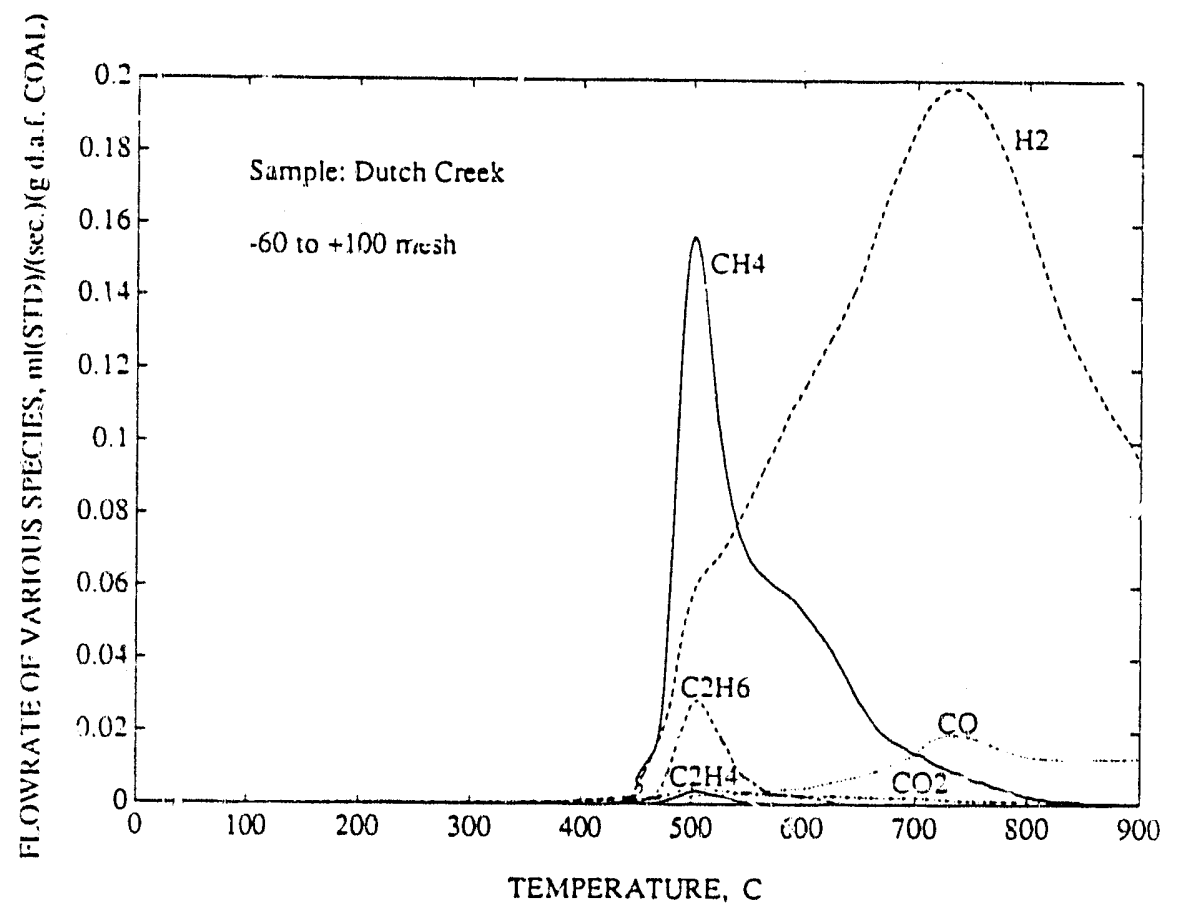

Figure 11. Pyrolysis gas yields as a function of temperature for Dutch Creek ccal.

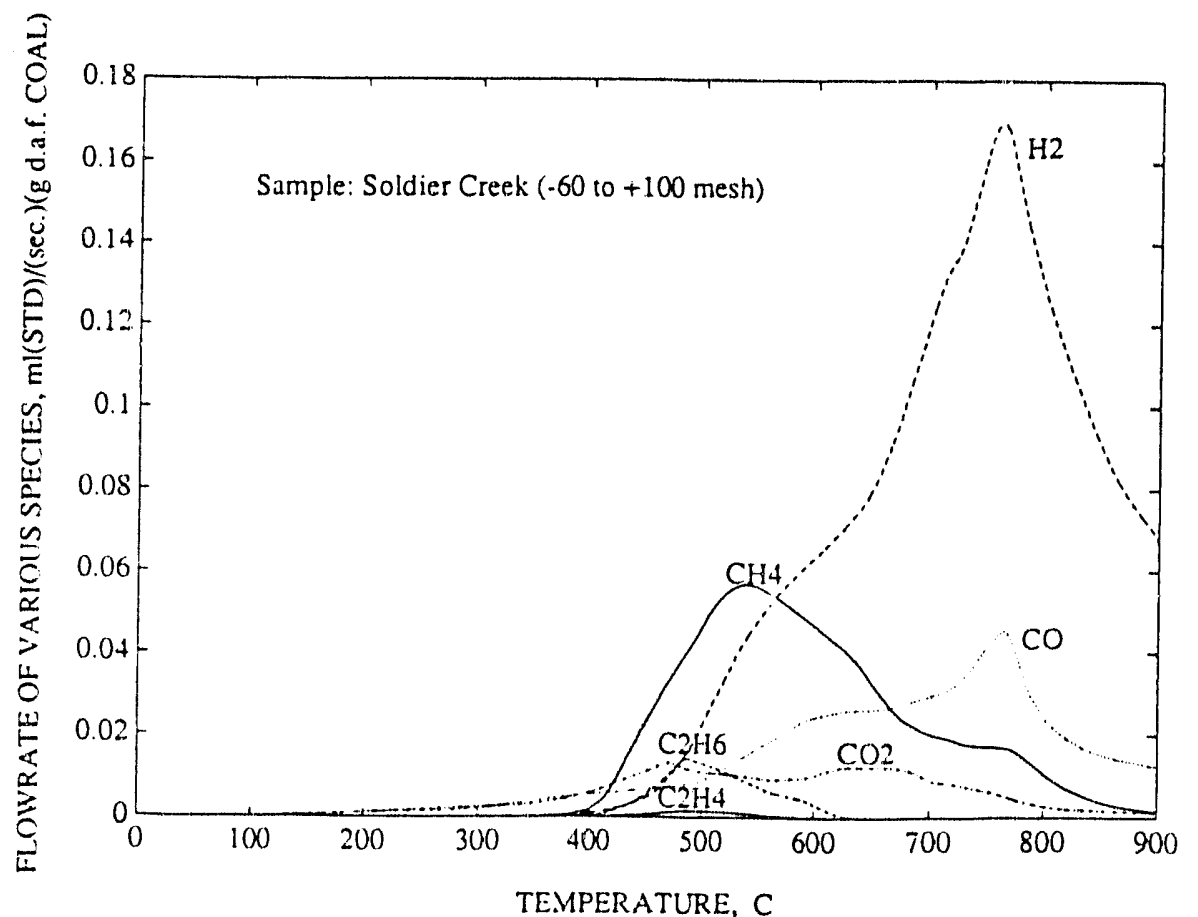

Figure 12. Pyrolysis gas yieids as a function of temperature soldier canyon coal. 


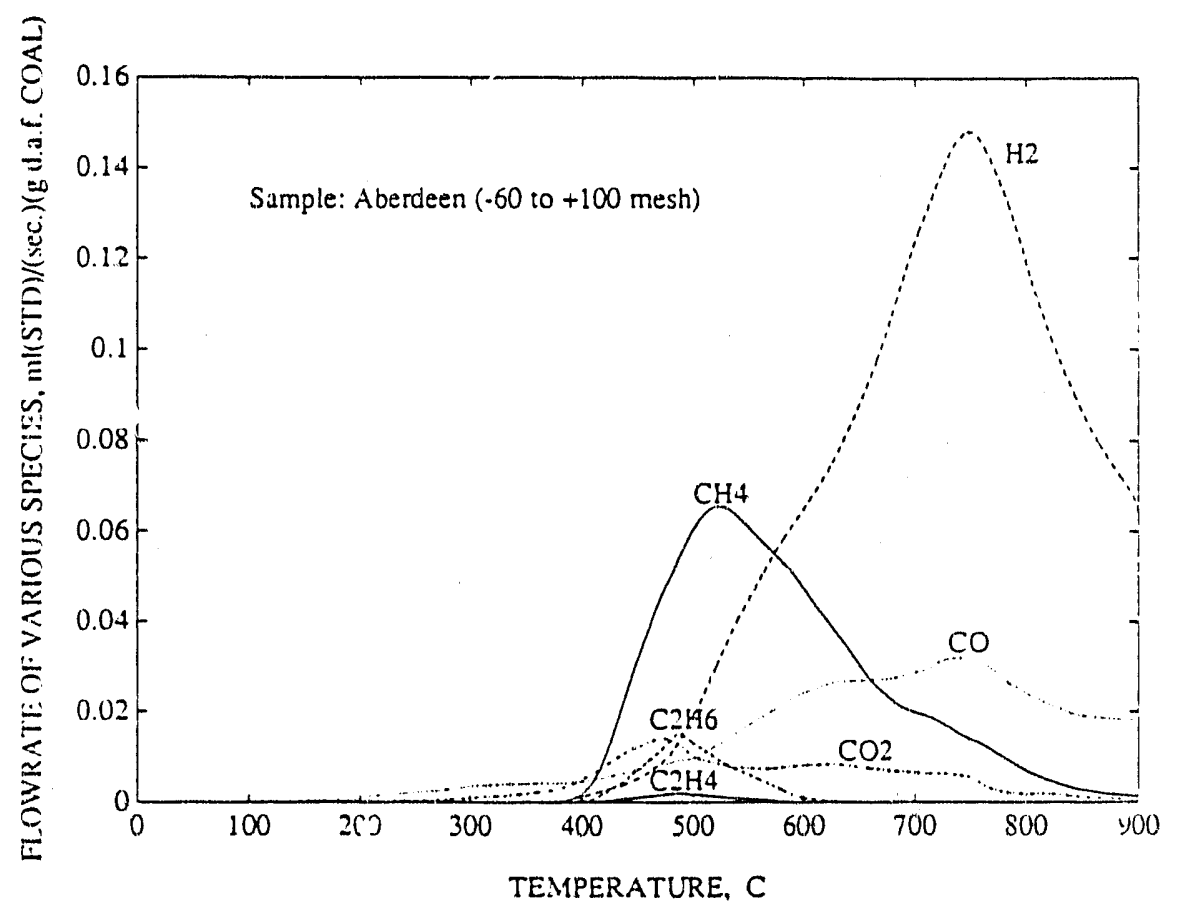

Figure 13. Pyrolysis gas yields as a function of temperature for Aberdeen coal.

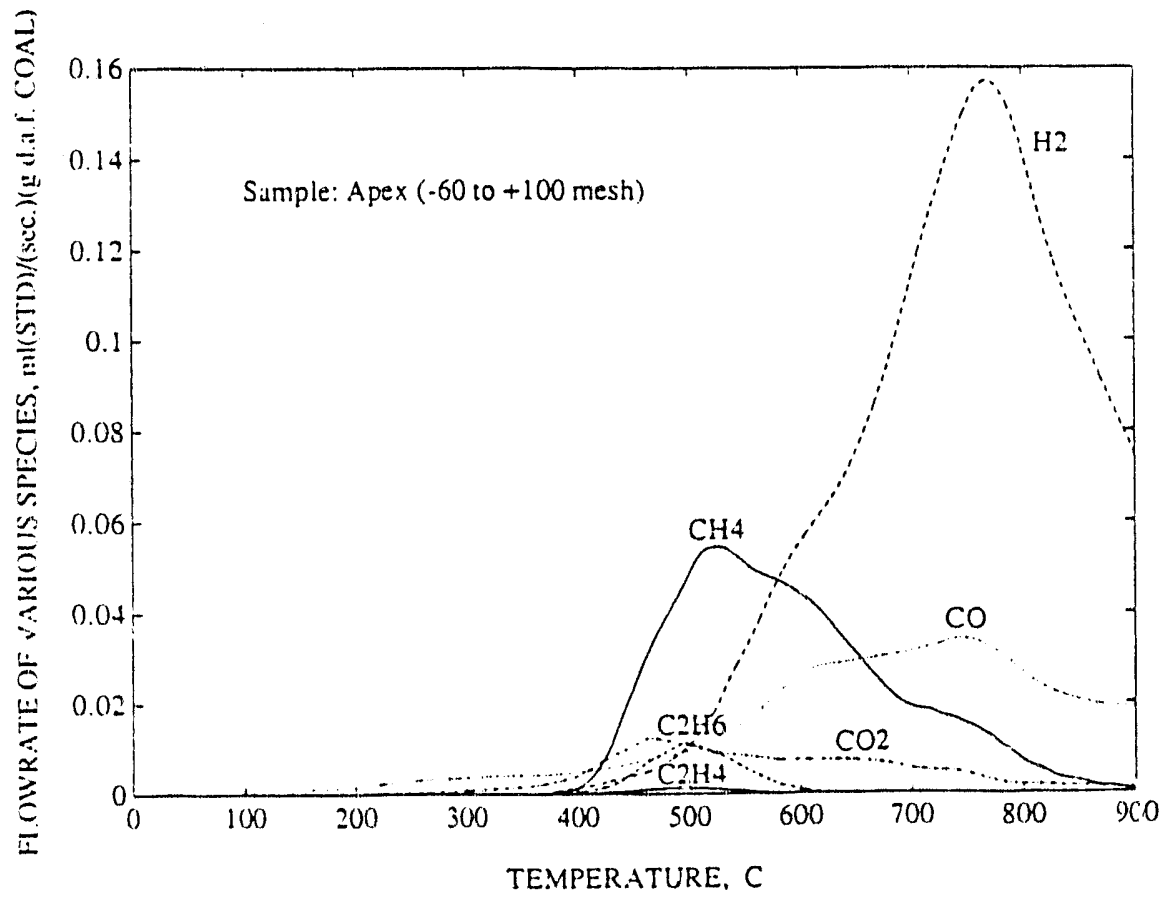

Figure 14. Pyrolysis gas yields as a function of temperature for Apex coal. 


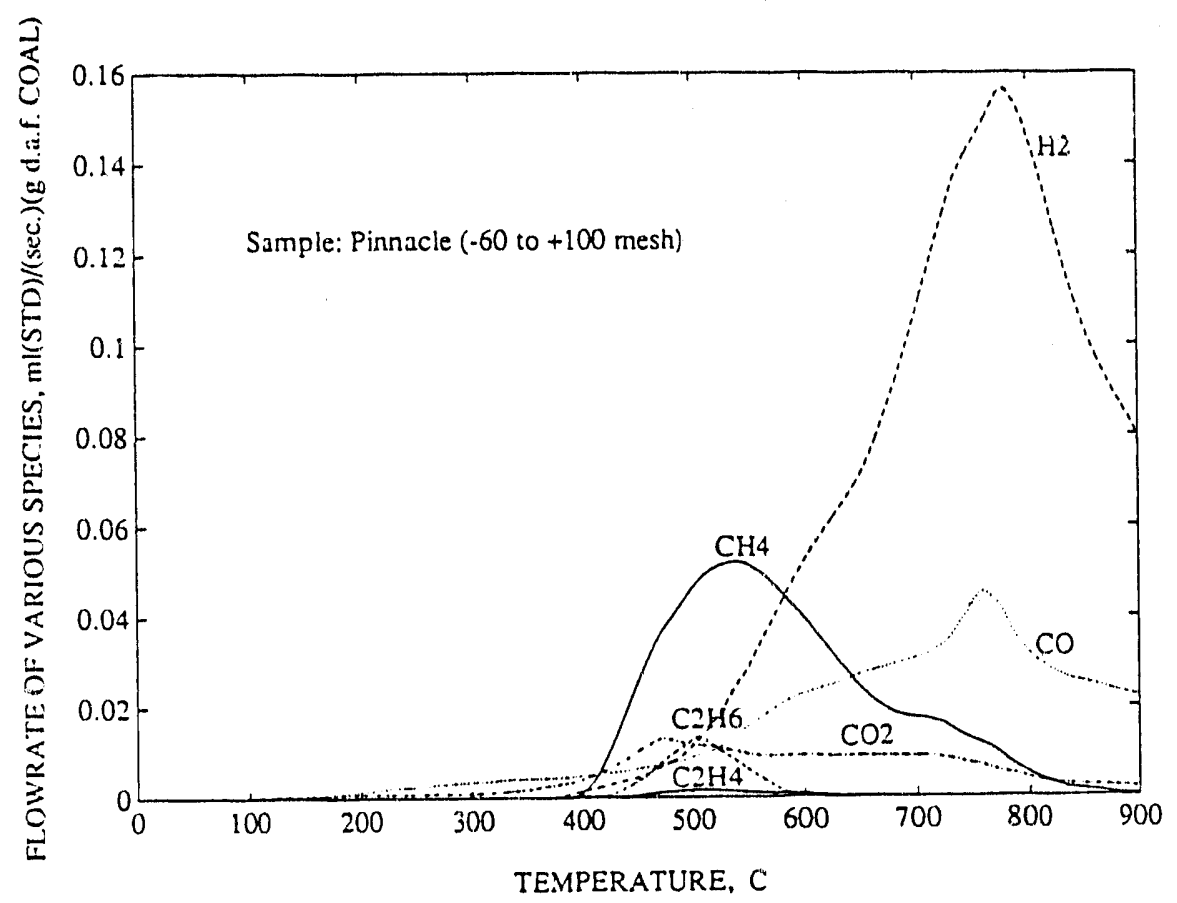

Figure 15. Pyrolysis gas yields as a function of temperature for Pinacle coal.

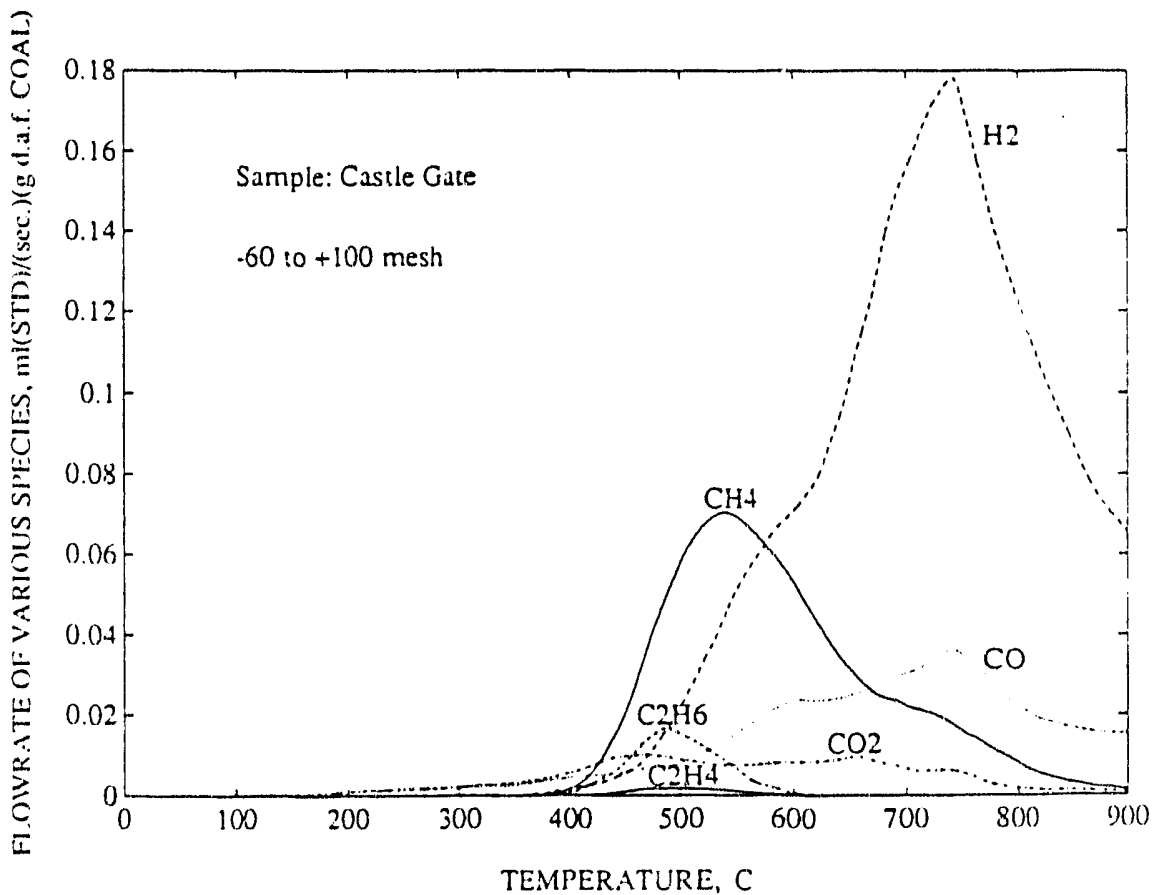

Figure 16. Pyrolysis gas yields as a function of temperature for Castle Gate coal. 


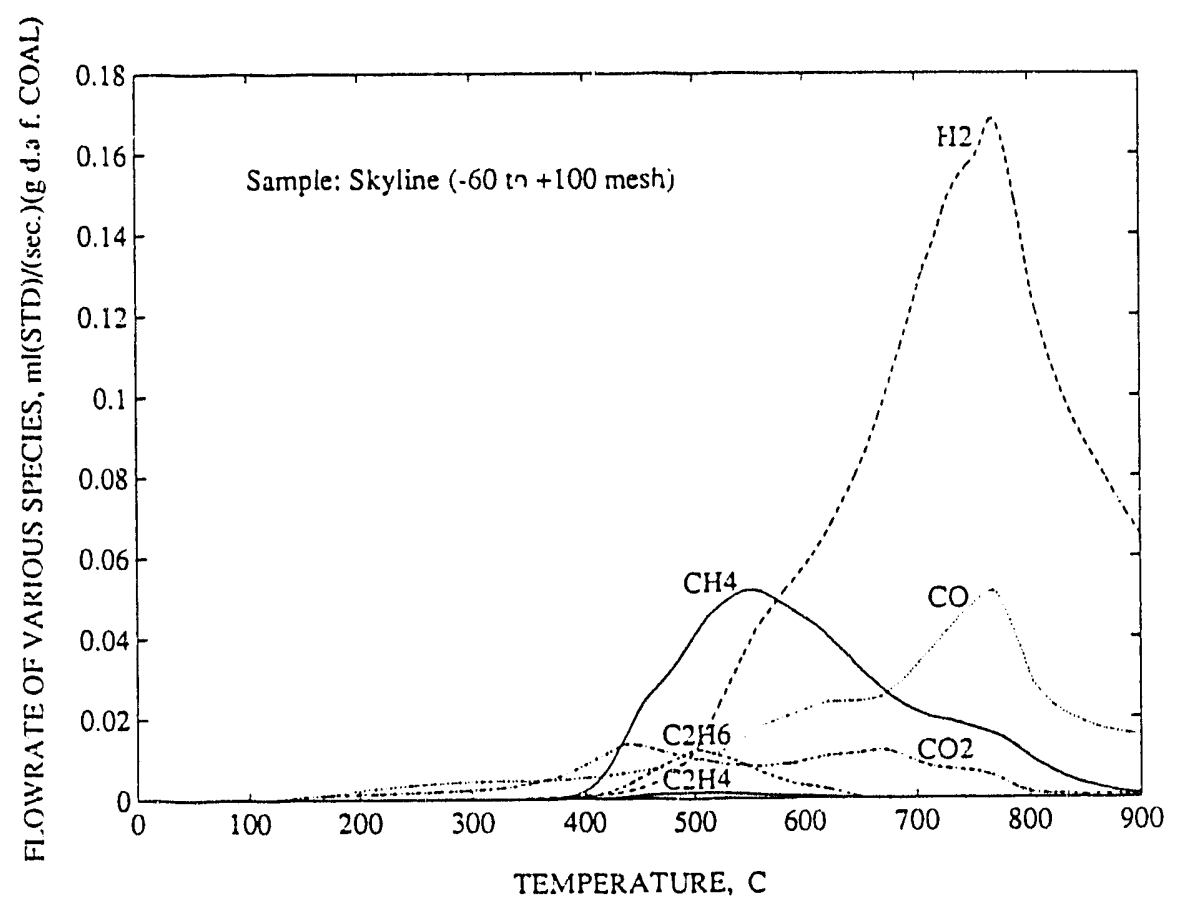

Figure 17. Pyrolysis gas yields as a function of temperature for skyline coal.

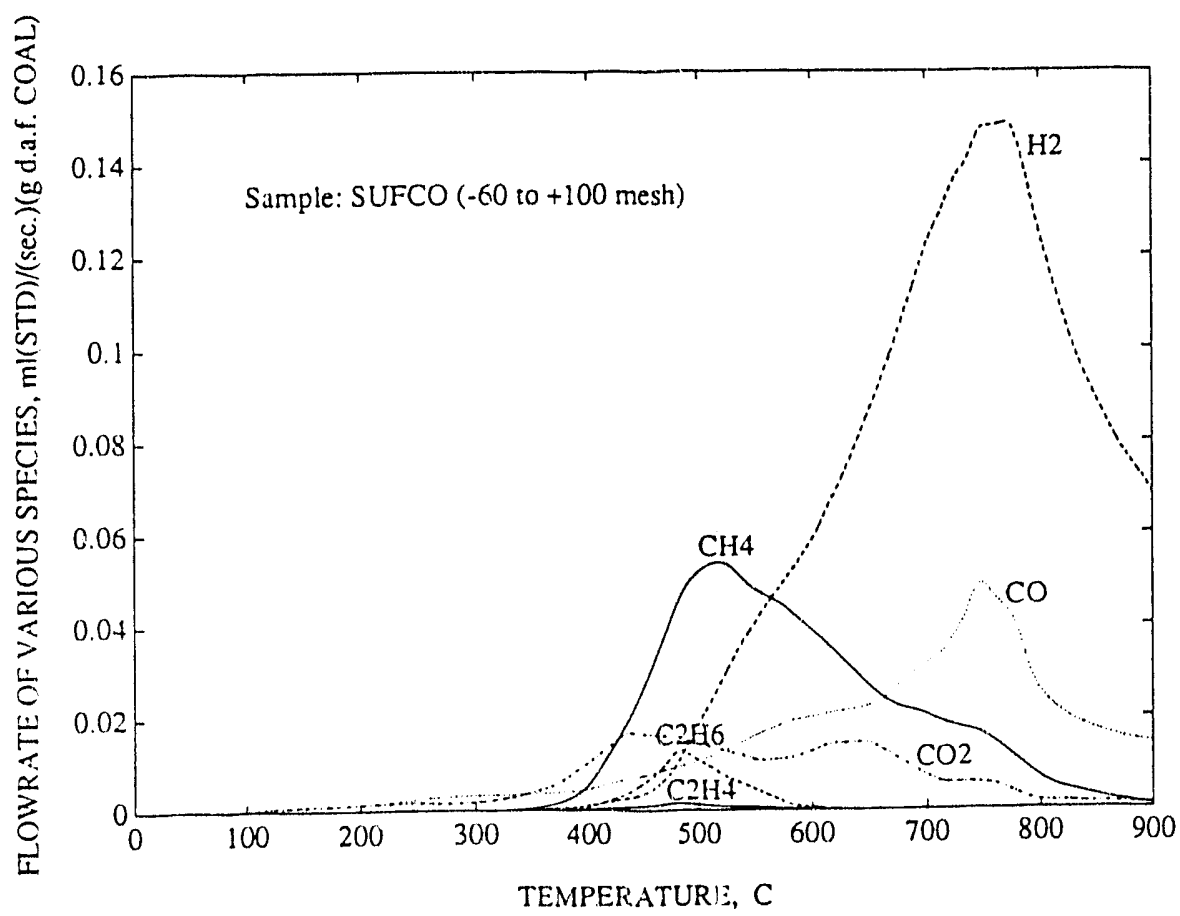

Figure 18. Pyrolysis gas yields as a function of temperature for sufco coal. 

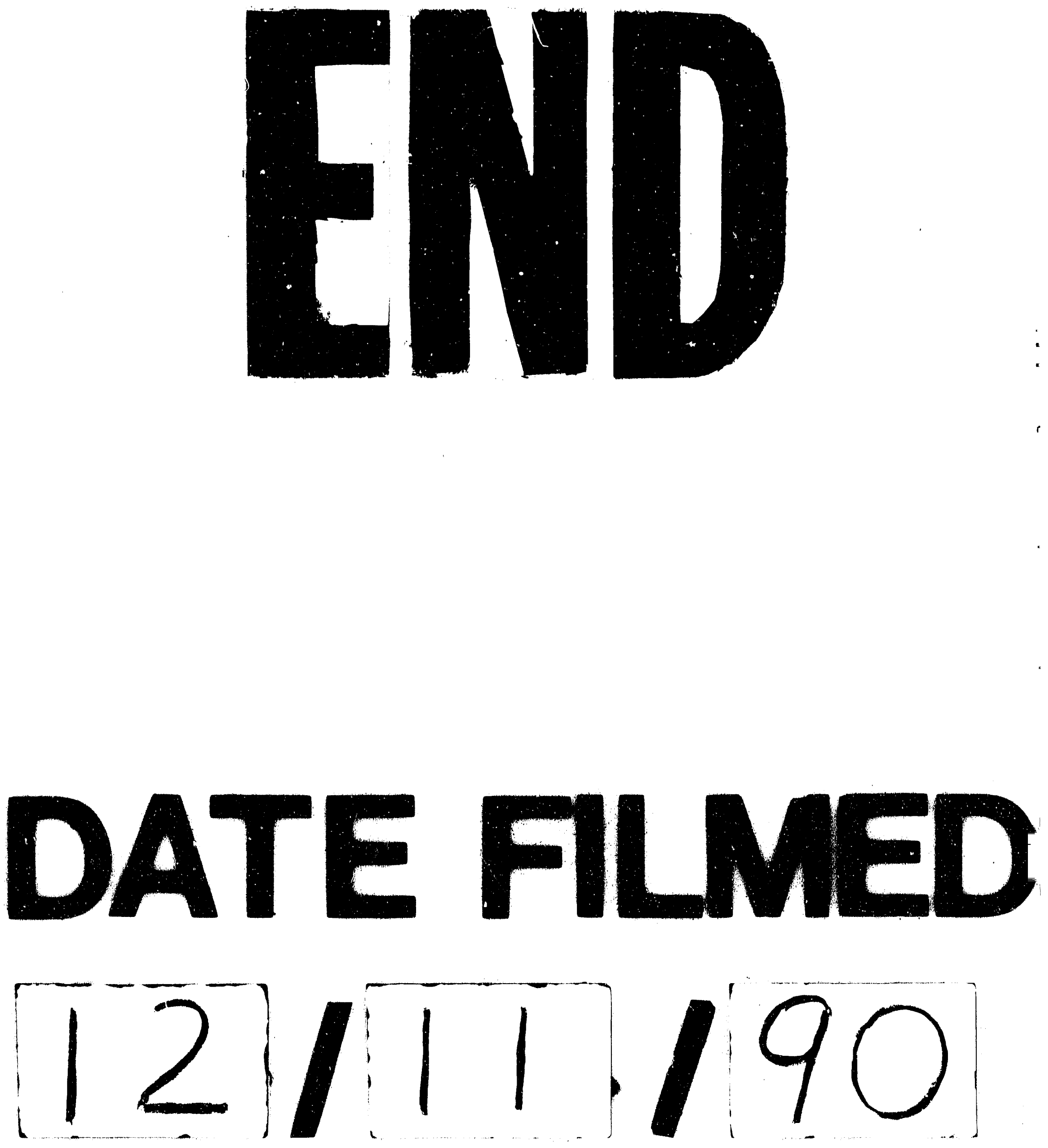
